\title{
Dimensioning the fear of dermatologic diseases *
}

\author{
Dimensionando o medo de doenças dermatológicas
}

\author{
Mariana Álvares Penha ${ }^{1}$ \\ Hélio Amante Miot ${ }^{2}$
}

\author{
Pamela Medeiros dos Santos ${ }^{1}$
}

\begin{abstract}
The symbolic representation of a disease is related to personal perceptions and cultural background. In the present study, the authors evaluate the population knowledge and fears related to skin and other prevalent or severe diseases. This survey was based on a semi-structured form to investigate demographic aspects, dermatologic consultations, fears and knowledge of 19 dermatoses and 11 prevalent or severe diseases. We interviewed 302 people, of which 54\% were women and the mean age was 39 years. Some fears of dermatoses surpass those of severe diseases. Skin cancer and total alopecia disclosed fears similar to that of myocardial infarction. - fundament, fundamentals - objective, objectives - method, methods - result, results - conclusion, conclusions

Keywords: Dermatology; Fear; Knowledge; Skin diseases; Social stigma

Resumo: A representação simbólica de doenças é ligada a percepções pessoais e raízes culturais. Neste estudo os autores avaliam o conhecimento e temores relacionados a dermatoses e outras doenças prevalentes ou graves na população. Este inquérito foi baseado em formulário semiestruturado para avaliar aspectos demográficos, consulta a dermatologistas, temores e conhecimento sobre 19 dermatoses e 11 doenças prevalentes ou graves. Foram entrevistadas 302 pessoas, sendo $54 \%$ do sexo feminino e a idade média, 39 anos. Certos temores de dermatoses superaram os de doenças graves, além disso, câncer de pele e alopecia total representaram temores semelhantes ao infarto do miocárdio. Fundamentos Objetivos Métodos Resultados Conclusões

Palavras-chave: Conhecimento; Dermatologia; Dermatopatias; Estigma social; Medo
\end{abstract}

The symbolic representation of diseases is related to personal perceptions and to the religious and cultural background of the social group in which it is inserted. ${ }^{1-3}$ Although we recognize more than 2000 dermatologic diseases, and more than $30 \%$ of healthcare clinics consultations evidence some dermatologic complaint, little information is given to the population regarding the semiotic representation of skin diseases. ${ }^{4,5}$

The skin is a large organ and an important medium to establish individual relationships with society. Visible dermatologic diseases can inflict social stress and impact on the patient's quality of life, no matter the degree of severity or symptomatology involved. ${ }^{1,6,7}$

Some failure in recognizing a dermatosis and delay in starting treatment can be caused by the patients' fear or shame. An assessment of the population stigmas regarding skin diseases can give some guidance to more efficient strategies for public education and health promotion. In the present work we focus on the population awareness related to skin diseases, previous dermatologic consultations, and habits of photoprotection.

We carried out a population inquiry directed to adult and adolescent passersby from Botucatu, Sao Paulo - Brazil. Interviews were made using a semistructured form to evaluate fears and knowledge of

\footnotetext{
Received on 01.12.2011.

Approved by the Advisory Board and accepted for publication on 30.03.2012.

* Study carried out at the Department of Dermatology and Radiotherapy at the School of Medicine of Botucatu - State University "Júlio de Mesquita Filho" (Faculdade de Medicina de Botucatu - Universidade Estadual Paulista "Júlio de Mesquita Filho" - FMB-UNESP) - Botucatu (SP), Brazil.

Conflict of interest: None

Financial funding: None

Medical student at the School of Medicine of Botucatu - State University "Júlio de Mesquita Filho" (Faculdade de Medicina de Botucatu - Universidade Estadual Paulista "Júlio de Mesquita Filho" - FMB-UNESP) - Botucatu (SP), Brazil.

PhD - Assistant Professor of the Department of Dermatology and Radiotherapy at the School of Medicine of Botucatu - State University "Júlio de Mesquita Filho" (Faculdade de Medicina de Botucatu - Universidade Estadual Paulista "Júlio de Mesquita Filho" - FMB-UNESP) - Botucatu (SP), Brazil. 
the names of dermatoses and severe or prevalent diseases. The project was approved by the ethical board of the institution (131/11).

The fear scores (huge, big, moderate, low, and no-fear) were tabulated and graphically represented by their frequencies. The patterns of diseases with similar fears were defined by examining the dendrogram (Ward analysis). Data were evaluated according to sex, age, and level of education by multivariate models. Significance level was set at two-tail $\mathrm{p}<0.05$. $^{8,9}$ Sample size was defined after a pre-test with 150 individuals (quota sampling). Interviews were conducted between May and October/2011 in the main streets of the city, at different scheduled times and days of the week. ${ }^{10}$ We interviewed 302 passersby, $54 \%$ were female and the mean age was 39 years. The skin diseases that were spontaneously most remembered as feared were: skin cancer (66\%), vitiligo (5\%), leprosy (2\%), and psoriasis (1\%). Fear perceptions are presented in figure 1. Skin cancer, total alopecia, vitiligo, syphilis, and leprosy were the dermatoses which presented higher fear scores. The dendrogram evidences groups of diseases with similar patterns. Interestingly, psoriasis and vitiligo resulted in a degree of fear similar to those of hypertension and diabetes; erysipelas were like osteoporosis; leprosy and syphilis were comparable to hepatitis; total alopecia and skin cancer have a degree of fear similar to that of myocardial infarction (Figure 2).

When analyzing the fears of all skin diseases, scores were higher for women $(p<0.01)$ and lower for the elderly $(\mathrm{p}<0.05)$. The lack of knowledge regarding the names of dermatologic diseases (10.7\%) was higher than that for other diseases $(3.0 \%)$ (p $<0.01)$, especially psoriasis $(61.9 \%)$, vitiligo $(37.4 \%)$, erysipelas (37.4\%), syphilis (19.2\%), and leprosy $(13.2 \%)$. Males $(\mathrm{OR}=2.0)$, the less educated $(\mathrm{OR}=$ $0.8)$, and the youngest $(\mathrm{OR}=0.9)$ were associated with the least knowledge related to names of skin diseases $(p<0.01)$.

The report of dermatologic consultations was more frequent in women $(61.1 \%$ vs. $39.3 \%$, p < 0.01$)$ and people of light phenotypes $(58.6 \%$ vs. $39.7 \%$,

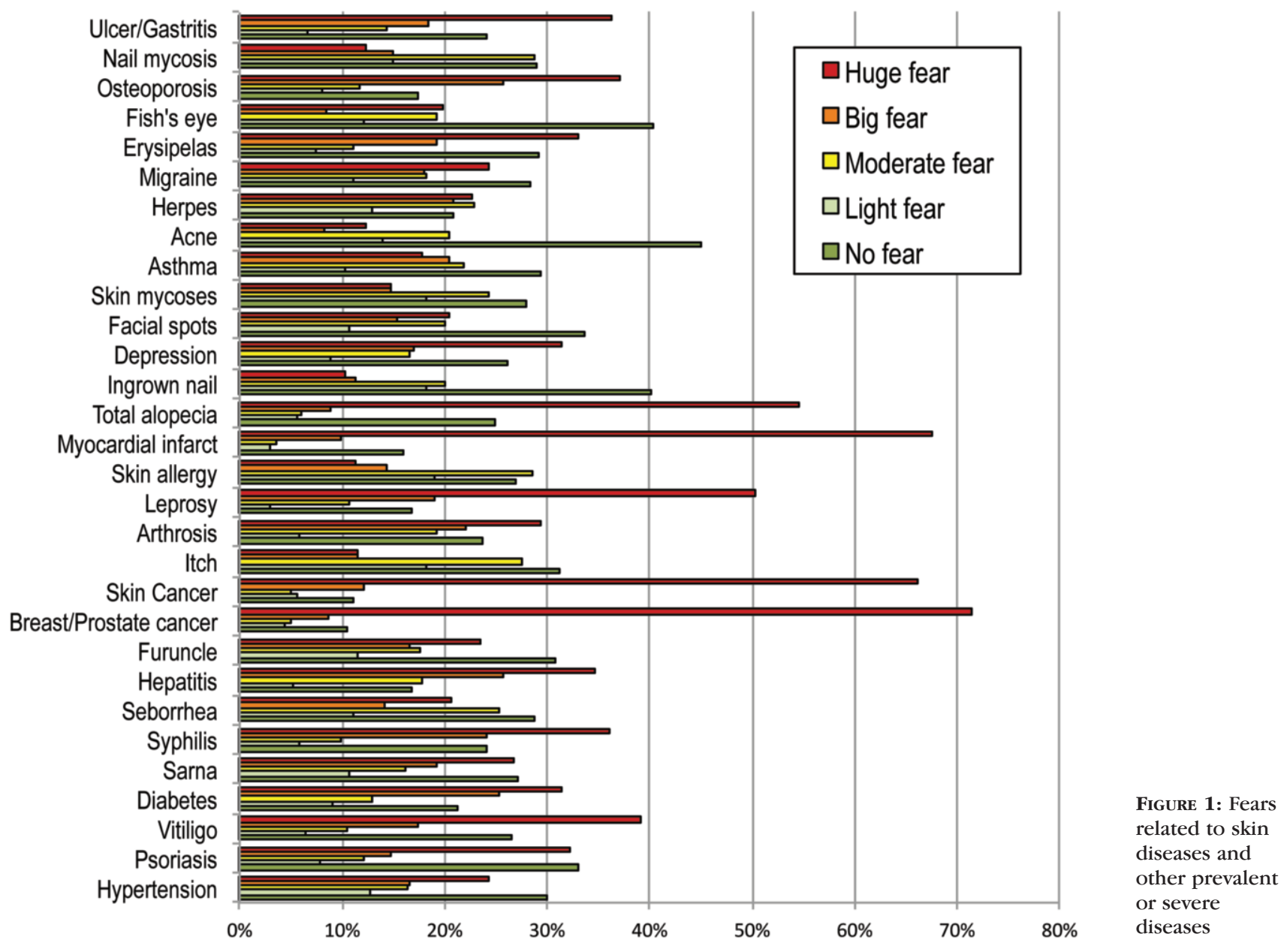


$\mathrm{p}<0.01)$, regardless of patient age $(\mathrm{p}>0.1)$. After multivariate adjustment, the female sex $(\mathrm{OR}=2.3)$ and light phenotype $(O R=2.0)$ remained significant $(\mathrm{p}<0.01)$. Daily sunscreen use was mentioned more frequently in women $(34.6 \%$ vs. $12.1 \%, \mathrm{p}<0.01)$, among those who had already visited a dermatologist $(35.7 \%$ vs. $12.2 \%, \mathrm{p}<0.01)$ and light phenotypes ( $45.4 \%$ vs. $10.4 \%, \mathrm{p}<0.01$ ). When adjusted by multivariate analysis, the use of daily sunscreen was independently associated $(\mathrm{p}<0.01)$ with female sex $(\mathrm{OR}=3.1)$ and previous consultation with a dermatologist

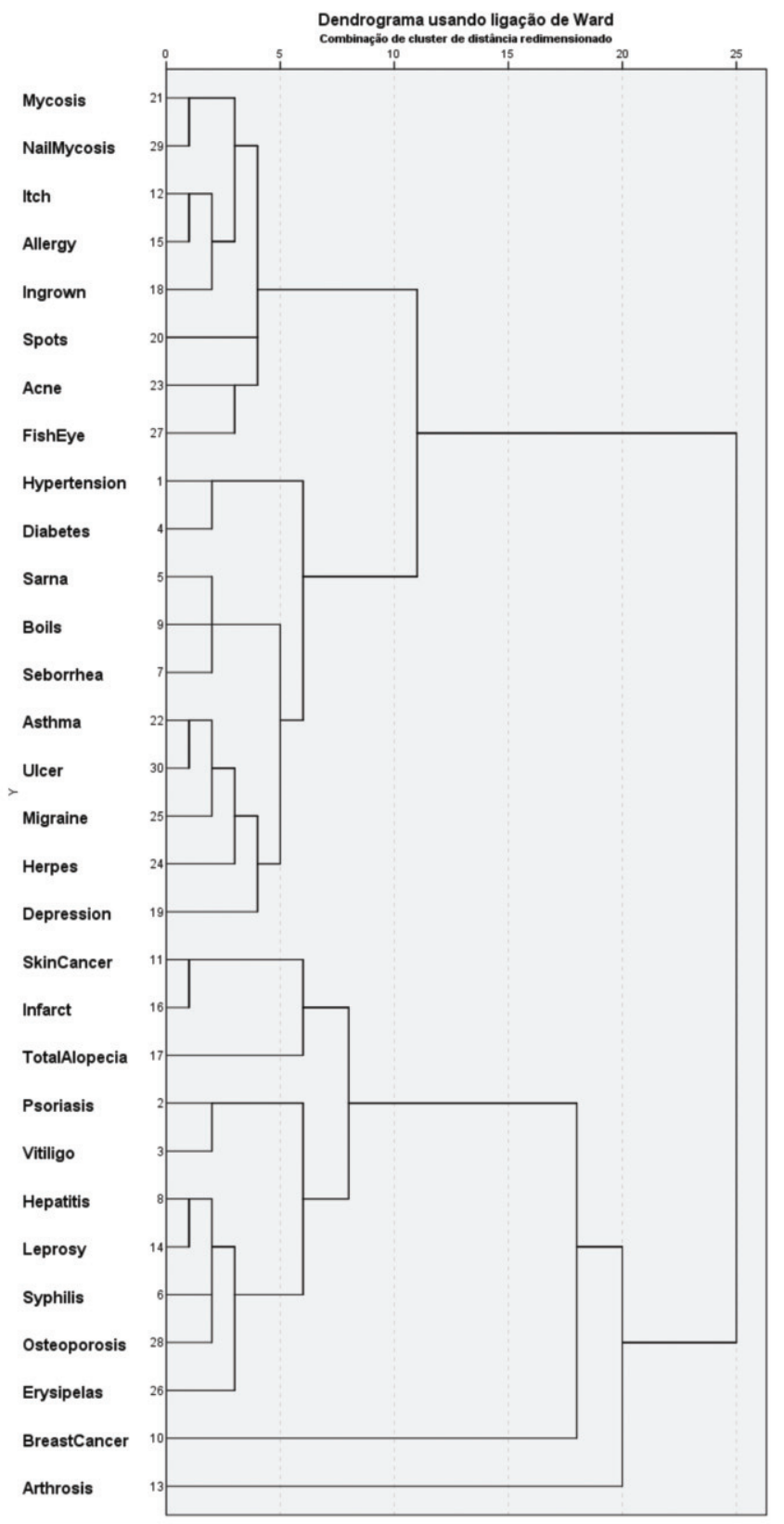

FiguRE 2: Dendrogram (Ward's method) of fear of disease scores
$(\mathrm{OR}=3.2)$, but not with light phototype $(\mathrm{p}=0.08)$. Older $(\mathrm{OR}=1.1)$, more educated individuals $(\mathrm{OR}=1.3)$, and women $(\mathrm{OR}=3.2)$ were associated with having previously consulted a dermatologist $(p<0.01)$, regardless of their skin phototype.

Our results have shown that the population is characterized by a significant lack of knowledge related to dermatologic diseases. In addition, some dermatoses inflict disproportional fears concerning their severity, and a few overwhelming fears of severe systemic diseases.

The promotion of a better population awareness regarding common dermatoses can be a public health strategy aiming at an early recognition and adequate treatment. Furthermore, it supports the process of publicizing dermatology (as a specialty) and its importance to society.

The fear of dermatoses which are spontaneously remembered (e.g. cancer, leprosy, and vitiligo) reinforce the fact that media exposure of those diseases can highlight the importance of dermatology. Moreover, strategies of mass publicity (e.g. TV, radio, and Internet) can promote population knowledge and, consequently, demystification of diseases and social prejudices.

The fact that women reported higher fear scores of dermatoses can be explained by the special importance of visual appearance in that group. Greater knowledge was also identified in that group, which can be supported by greater scores of fear and higher number of women in dermatologic consultations. ${ }^{4}$

Women also referred more prevalent everyday sunscreen use than men, as well as those who have consulted a dermatologist, suggesting the potential of dermatologic consultation on habit modification.

The important visual component inflicted by dermatoses makes an impact on the population, generates social stigma and can favor the efficiency of educational campaigns, which should focus also on illiterate people, young people, and men. The main limitation of the present study is related to the sample composed exclusively of healthy passersby from a city in the interior. Nevertheless, the quota sampling ensured suitable representativeness of the different strata: sex, scholarship, age-group, and skin phototype.

In conclusion, a fraction of the population is not well informed about dermatologic diseases, and consequently some dermatoses inflict remarkable fear on the population. Educational policies can promote the population's skin health by increasing information, providing more accurate diagnosis and decreasing prejudice. 


\section{REFERENCES}

1. Chaturvedi SK, Singh G, Gupta N. Stigma experience in skin disorders: an Indian perspective. Dermatol Clin. 2005;23:635-42.

2. Elissen MC. Beliefs of leprosy patients about their illness. A study in the province of South Sulawesi, Indonesia. Trop Geogr Med. 1991;43:379-82.

3. de Oliveira DC, de Sa CP. Representações sociais da saúde e doença e implicações para 0 cuidar em enfermagem: uma análise estrutural. Rev Bras Enferm. 2001;54:608-22.

4. Sociedade Brasileira de Dermatologia SBD. Perfil nosológico das consultas dermatológicas no Brasil. An Bras Dermatol. 2006;81:549-58.

5. Oliveira TF, Monteguti C, Velho PE. Prevalence of skin diseases at a healthcare clinic in a small Brazilian town. An Bras Dermatol. 2010;85:947-9.

6. Silvares MR, Fortes MR, Miot HA. Quality of life in chronic urticaria: a survey at a public university outpatient clinic, Botucatu (Brazil). Rev Assoc Med Bras. 2011;57:577-82.

7. Schmid-Ott G, Künsebeck HW, Jecht E, Shimshoni R, Lazaroff I, Schallmayer S, et al. Stigmatization experience, coping and sense of coherence in vitiligo patients. J Eur Acad Dermatol Venereol. 2007;21:456-61.

8. Norman GR, Streiner DL. Biostatistics. The bare essentials. 3rd ed. Shelton, Connecticut: People's Medical Publishing House; 2008.
9. Katz MH. Multivariable analysis. A practical guide for clinicians. 2nd ed Cambridge, UK: Cambridge University Press; 2006.

10. Miot HA. Tamanho da amostra em estudos clínicos e experimentais. J Vasc Bras. 2011;10:275-8.

MAILING ADDRESS:

Hélio Amante Miot

Departamento de Dermatologia, $S / N$

Faculdade de Medicina da UNESP

Campus Universitário de Rubião Jr.

18618-970 - Botucatu, SP.

E-mail: heliomiot@fmb.unesp.br

How to cite this article: Penha MA, Santos PM, Miot HA. Dimensioning fear of dermatologic diseases. An Bras Dermatol. 2012;87(5):796-9. 